
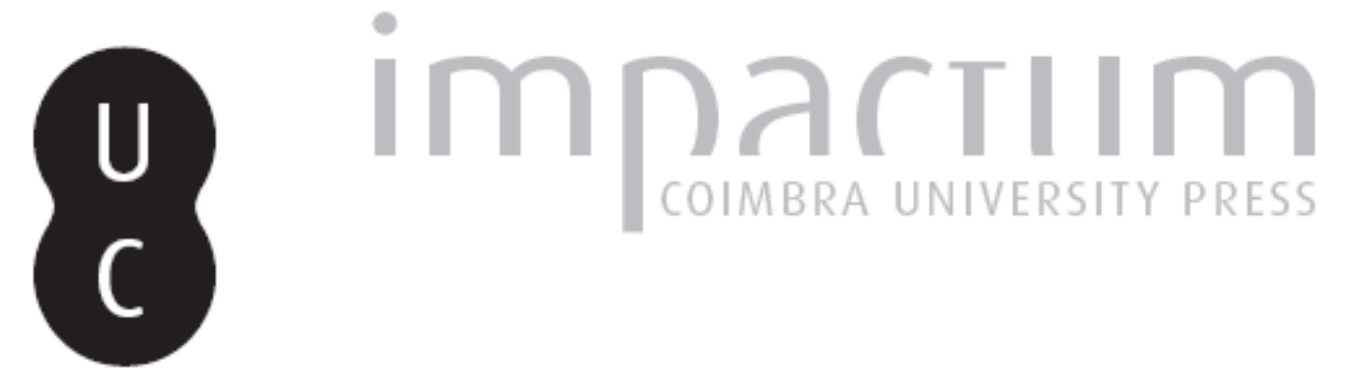

\title{
Phaedrus, lon, and the lure of inspiration
}

\section{Autor(es): Dixon, Barry}

Publicado por: Imprensa da Universidade de Coimbra

URL persistente:

URl:http://hdl.handle.net/10316.2/42207

DOI:

DOI:https://doi.org/10.14195/2183-4105_8_1

Accessed : $\quad$ 26-Apr-2023 10:52:56

A navegação consulta e descarregamento dos títulos inseridos nas Bibliotecas Digitais UC Digitalis, UC Pombalina e UC Impactum, pressupõem a aceitação plena e sem reservas dos Termos e Condições de Uso destas Bibliotecas Digitais, disponíveis em https://digitalis.uc.pt/pt-pt/termos.

Conforme exposto nos referidos Termos e Condições de Uso, o descarregamento de títulos de acesso restrito requer uma licença válida de autorização devendo o utilizador aceder ao(s) documento(s) a partir de um endereço de IP da instituição detentora da supramencionada licença.

Ao utilizador é apenas permitido o descarregamento para uso pessoal, pelo que o emprego do(s) título(s) descarregado(s) para outro fim, designadamente comercial, carece de autorização do respetivo autor ou editor da obra.

Na medida em que todas as obras da UC Digitalis se encontram protegidas pelo Código do Direito de Autor e Direitos Conexos e demais legislação aplicável, toda a cópia, parcial ou total, deste documento, nos casos em que é legalmente admitida, deverá conter ou fazer-se acompanhar por este aviso.

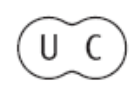




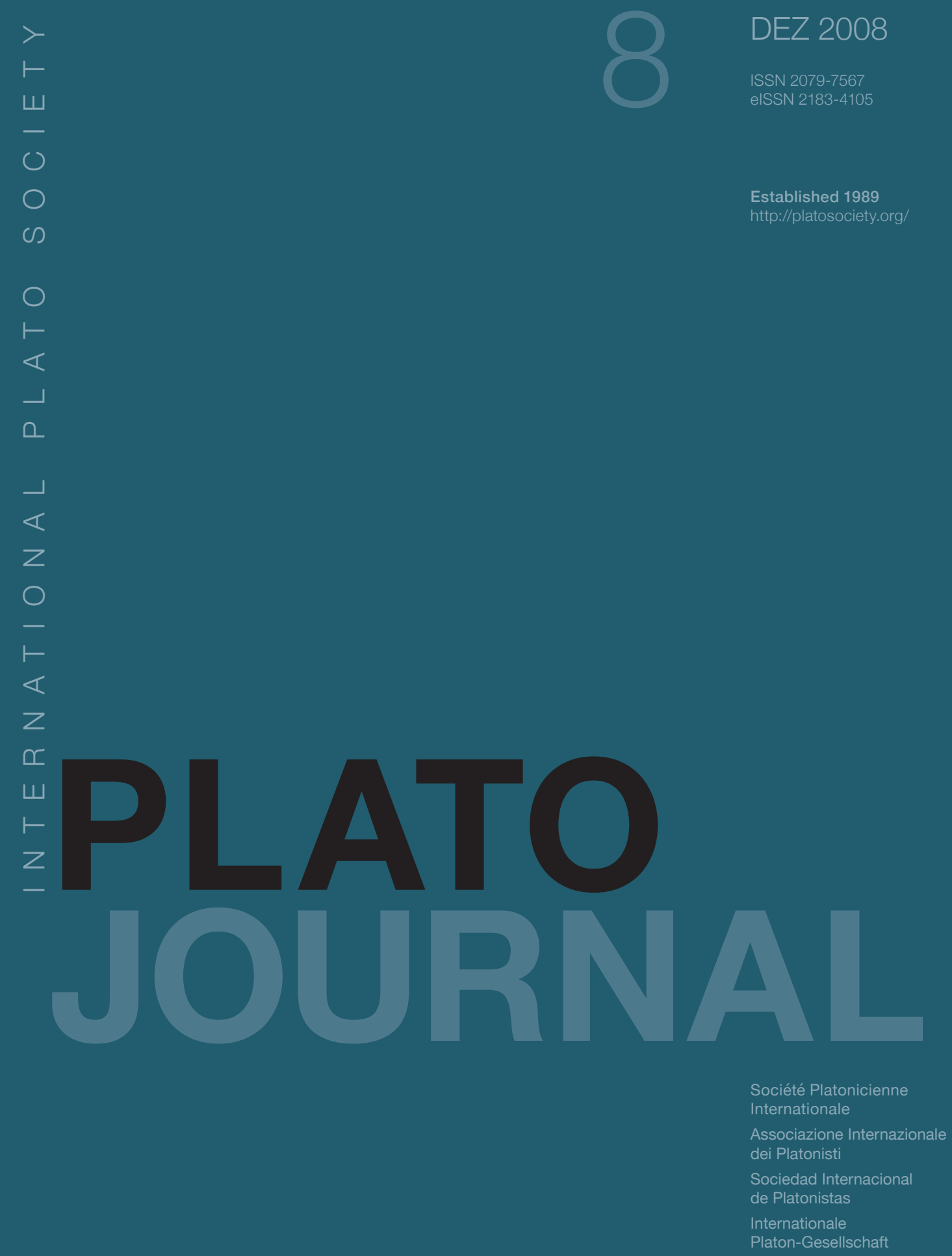




\section{PHAEDRUS, ION, AND THE LURE OF INSPIRATION}

\section{Introduction}

One of the most recognisable aspects of Plato's richly designed characterisation of Socrates is undoubtedly his use of irony and the ironic argument. Not only does this feature help paint the many colours of Socrates' persona, it also acts as a highly operative part of his dialectical methodology. Although Socrates' confession of ignorance in Plato's earlier works is generally held to be one aspect of Socratic irony, it is not the whole story. Other features, such as the blatant use of sarcasm (as seen, for example, in Socrates' greeting of Agathon at Symposium 175e), are just as important in Plato's detailed portrayal of Socratic irony. Yet, undoubtedly the most difficult element of Socratic irony from a contemporary, interpretive position, is when Socrates propounds a position that he is intending to argue against, showing, through question and answer, the position's ultimate fallibility. Perhaps the most paradigmatic and, indeed, prolonged example of this method can be seen in the Hippias Minor. For this whole dialogue is an ironic lampoon of the use of Homer to suit any ethical outlook or position, a damaging type of sophism which was prevalent in Plato's time. This can be seen in the work's concluding lines, which are uncharacteristically conclusive.

Therefore, Hippias, the person, if he exists, who deliberately makes mistakes and acts contemptibly and criminally, can only be the good person. Hippias Minor, 376b

Of course, it is quite easy to spot the irony in this case, given how utterly foreign its message is to what we may call a 'regular' Platonic position. In other cases, however, this distinction is not always so clear cut. In these cases a danger arises that an argument that was meant ironically is taken literally. The esoteric route of such discussions can invariably lead to misrepresentations of Platonic philosophy. One such misrepresentation is prevalent, I believe, in the case of Plato's apparent

PLATO, The electronic Journal of the International Plato Society, n 8, 2008.

http://gramata.univ-paris1.fr/Plato

(c) All rights of reproduction of any form reserved. 
lauding of divine inspiration in the Phaedrus ${ }^{1}$. What this paper hopes to show is the degree of irony in Socrates' comments on divine inspiration in this work, and how connected the use of irony here is to the mechanics of dialectic, using Plato's Ion as a comparative example ${ }^{2}$. Although the use of irony in the Ion is generally admitted by commentators, the same certainly cannot be said for the Phaedrus. What I also hope to show is how it is the characters in each dialogue which draws Socrates' use of irony, with his approach carefully suited and catered for each interlocutor.

My argument is divided into three adjoining sections. The first deals with the first speech of Socrates' in the Phaedrus $(237 \mathrm{~b}-241 \mathrm{~d})$ as well as the more general theme of Plato catering his dialogues and arguments to suit his carefully chosen interlocutors. The evidence to support this will come from the Phaedrus itself. My second section shows the importance of this variegated style to the Ion and its detailed description of the inspired condition. Finally, my third section will treat perhaps the most quoted section of the Phaedrus, Socrates' palinode, where inspiration is given its most (in)famous celebration. All in all, my focus is not on discussing the notion of Socratic irony as a concept, but rather in showing how Socrates' description of divine inspiration in the Phaedrus and Ion, is itself wholly ironic.

\section{Socrates' First Speech from Phaedrus 237b - 241d}

Socrates' first speech is one which he does not want to give. Having had Phaedrus recite Lysias' address on Love, Socrates is coerced into giving a response, though

\footnotetext{
${ }^{1}$ All of the great commentaries on the Phaedrus, such as those of Hackforth (1952), Griswold (1986), and Ferrari (1987) appear to me to accept the references to inspiration at face value.

2 Any work on inspiration must acknowledge E.N. Tigerstedt's "Furor Poeticus: Poetic Inspiration in Greek Literature Before Democritus and Plato", Journal of the History of Ideas, XXXI [1970], 163-78, in which Tigerstedt argues that Plato's conception of inspiration as possession is wholly original. Without contradicting Tigerstedt, I argue that Plato uses a traditional belief in inspiration to help accomplish his goals. Plato's leap from inspiration to possession can be seen, therefore, as being part of this usage. Tigerstedt's other important work on inspiration, Plato's Idea of Poetical Inspiration (1969) is similarly helpful in critically assessing what were the current scholarly opinions on the matter.
}

PLATO, The electronic Journal of the International Plato Society, n 8, 2008.

http://gramata.univ-paris1.fr/Plato

(c) All rights of reproduction of any form reserved. 
from the same point of view as that of Lysias. That this speech is intended ironically cannot be denied, given how much persuasion is required by Phaedrus to get Socrates to do it, not to mention the fact that Socrates dons a hood for the duration before expressing his disgust at himself once the speech is finished ${ }^{3}$. Yet Socrates also admits to something extraordinary happening to him during this first speech. For he makes a point of telling Phaedrus that the speech is coming, 'through my ears, as into a vessel, from some external source' (Phaedrus, 235c-d). Given how inspiration as a driving force in this speech is re-iterated by Socrates at $237 \mathrm{a}, 238 \mathrm{c}$, and at $238 \mathrm{~d}$, its introduction as a theme is thereby introduced. Of course, as mentioned, this speech is intended ironically. What is established, then, is an initial connection between the theme of inspiration and an ironic speech.

But why would Socrates feign this belief in inspiration in the first place? The reason lies, I believe, in the character of Phaedrus. As especially seen in the middle and late Platonic dialogues, each interlocutor is introduced into the works in order to be persuaded of one thing: the centrality of philosophical dialogue in the advancement of knowledge. Their discussion with Socrates, or with the Athenian or Stranger, is invariably designed so that they would be persuaded of this. As seems clear, these interlocutors were also chosen for being representatives of certain philosophical schools of thought or positions. What this means, though, is that some approaches are suitable to only a certain type of listener. Catering Socrates' approach is, consequently, something much adhered to by Plato in his choices of interlocutor. One needs to understand ones audience, then, or at least attempt to understand, if one is to be successful in this endeavour. This is not my hypothesis alone, but is taken directly from the later parts of the Phaedrus itself. Here it is presented as being a key part of the newly conceived philosophical rhetoric ${ }^{4}$.

\footnotetext{
${ }^{3}$ He even calls it 'blasphemous' at Phaedrus, $242 \mathrm{~d}$.

4 All of my quotations of the Phaedrus come from Hackforth's (1952) translation. I am using Hackforth's translation because in the commentary of his translation he adhered to the belief that Plato is a serious advocate of inspiration. By using Hackforth's translation, therefore, I cannot be accused of seeing only what I want to see in my own translations.
}

PLATO, The electronic Journal of the International Plato Society, n 8, 2008.

http://gramata.univ-paris1.fr/Plato

(c) All rights of reproduction of any form reserved. 
"Hence a certain type of hearer will be easy to persuade by a certain type of speech to take such-and-such action for such-and-such reason, while another type will be hard to persuade." (Phaedrus, 271d)

In other words, not all speeches will work all types of people. As Socrates is in a discussion with Phaedrus, a discussion in which he ultimately wants to convince him of the superiority of philosophy, he will need to cater his approach to suit ${ }^{5}$. Now, Socrates knows already the type of person Phaedrus is, meaning he already knows the type of approach he will require. Plato seems to be quite blatant in telling us this, when he has Socrates assert the following.

"I know my Phaedrus; yes indeed, I'm as sure of him as of my own identity." (Phaedrus, 228a)

We too have a picture of Phaedrus, not just from this work but from the Symposium. What seems clear is that a detailed discussion of mathematics or on some specific theory of knowledge would be utterly unsuited to persuading him of the benefits of philosophical discussion. How Plato designs the discussion, then, centres on Socrates approaching his subject through somewhat literary means ${ }^{6}$. For example, we can say that the concept of the 'soul' figures quite prominently in this discussion, as it does in, lets say, the Phaedo. In the Phaedo, Socrates approaches his Pythagorean interlocutors from the basis of a mathematical inconsistency with regard to their notion of the soul, a theory of symbiosis which was at the heart of Pythagorean metaphysics. Here in the Phaedrus, however, this approach is nowhere to be found and a series of mythical speeches takes its place. Divine inspiration, then, is part of this carefully designed approach.

So back to Socrates' first speech on Love where we find the theme of inspiration littered throughout a speech that Socrates acknowledges as being

\footnotetext{
${ }^{5}$ We find Socrates conceding his intentions at Phaedrus, $257 \mathrm{~b}$ where he grants his motivation was to persuade Phaedrus to 'live for Love in singleness of purpose with the aid of philosophical discourse.'

${ }^{6}$ We even have Socrates admit this later in the dialogue when he acknowledges that the language he used in his treatment of Love was 'perforce poetical, to please Phaedrus.' (Phaedrus, 257a)
}

PLATO, The electronic Journal of the International Plato Society, n 8, 2008. http://gramata.univ-paris1.fr/Plato

(c) All rights of reproduction of any form reserved. 
harmful. I believe the reason Plato has Socrates deliver this speech is because of his plans for persuading Phaedrus of the benefits of philosophy. For in this speech, Socrates delivers quite a convincing argument for a position he did not believe in. This type of ethical waste-ground was a common feature of the sophists, Lysias included, whereby they would train their students to adopt any side of an argument as their own, despite their personal feelings on the matter. We find this very thing done by Socrates here in this first speech. However, unlike the sophists, he is disgusted with himself afterwards, vehemently warning Phaedrus off such an approach. Inspiration fits into Plato's plans by creating a distance between what Socrates says and what is actually meant. By attributing the speech, not to Socrates, but to some 'other' source, licence is given to have one thing said but quite another thing meant. It is like a warning of incoming irony.

\section{The Irony of the Ion and the Inspired Condition}

The link between Plato's treatment of divine inspiration and an ironic Socratic speech is exemplified in the Ion. The very fact that speeches are used, as opposed to a discussion, is a further instance of evidence for an ironic Platonic sentiment. Socrates' speech here, from $533 \mathrm{~d}-535 \mathrm{a}$, is a perfect example of an ironic speech given how it seems to be offering praise but is actually degrading both the rhapsode's and poet's art, by taking from them any claim to knowledge. It is a purposefully absurd speech, as noted by Woodruff, given the fact that it is literally false. For, throughout the dialogue Ion recites extracts from Homer. According to Socrates' arguments, Ion must have been possessed during these recitations, something that is plainly absent from the dialogue. Not only this, but Socrates himself quotes lengths of Homeric text. Does this mean that he too was in an inspired state during these recitations? So the point of the detailed tale of inspiration, then, cannot be argumentative and most certainly cannot be a genuine Platonic belief.

Why, though, is inspiration used? Again, I believe this lies with the interlocutor and what he represented. Although presented as a much more simple-minded

\footnotetext{
${ }^{7}$ Paul Woodruff (1983), “The first thing to notice about Plato's account of inspiration is that it is literally false.” Introduction, p. 8.
}

PLATO, The electronic Journal of the International Plato Society, n 8, 2008. 
discussant than Phaedrus, Ion represents an extremely important section of society for Plato to address. For the recitation of Homer was a central part of the Athenian educational system. Rhapsodes, by making the recitation of Homer their profession, were furthering a pedagogical ideal which Plato felt was harmful and ethically damaging. Also, given the extent to which Athens was an oral culture, the majority of Athenians were exposed to Homer through the recitations of these rhapsodes ${ }^{8}$. Behind Plato's treatment of the rhapsodes, then, was a vicarious attack on this educational system. Yet, if Plato's target was so important, why then is his approach towards Ion rather comical? Does a reading of the Ion not betray a rather flippant attitude on the part of Socrates? Well, yes it does, but that is because of the class of people represented by Ion. Just like Socrates' 'perforce poetical' approach towards Phaedrus, so too is his treatment of Ion one of careful design, which caters directly for those whom Plato wished to address. For starters, although historical evidence detailing any specifics on rhapsodes is scarce, what we do have tends to lead us to consider them to have been somewhat dim, superficial and ultimately shallow individuals'. The idea of Socrates launching a barrage of detailed questions concerning Ion's concept of epistemology would never have suited the character he was or the profession he was part of. Instead, Socrates succeeds in taking from the rhapsodes and poets any claim to knowledge by using divine inspiration, an ironic speech which Ion eventually embraces. I do not believe Plato intended this as a genuine sentiment because of how perfectly it accomplishes its mission. Why bother with mathematics or analytic argumentation when your discussant will gladly agree with you on the evidence of a simple speech? Inspiration achieves Plato's task in the most efficient and suitable way for the type of interlocutor at hand.

Of course, as mentioned, Ion also embodied a belief in Homer which most Athenian citizens were told to adhere to. In a sense, then, the Ion can be said to be

${ }^{8}$ That rhapsodic recitations were popular can be seen in Xenophon's Symposium, III, where Niceratus' father is said to have listened to rhapsodic performances every day. Also, the fact that rhapsodic competitions survived hundreds of years similarly indicates their popularity.

9 The most apparent indication of this comes again from Xenophon's Symposium, where Antisthenes wonders how Niceratus can take pride in knowing the works of Homer when this is a feat done by the rhapsodes who are, he asserts, the most stupid of men. A sign that this is not just a solitary belief comes from the fact that all characters in Xenophon's work accept Antisthenes' assertion without question, even those who are presented as proponents of Homer.

PLATO, The electronic Journal of the International Plato Society, n 8, 2008.

http://gramata.univ-paris1.fr/Plato

(c) All rights of reproduction of any form reserved. 
addressing these citizens too. The work is not too long or overly complicated meaning anyone could follow it, especially those without experience in philosophical argumentation. Treating one's audience differently according to their level of education is even admitted to by Socrates in the Phaedrus where one is advised to 'order and arrange your discourse accordingly, addressing a variegated soul in a variegated style that ranges over the gamut of tones, and a simple soul in a simple style' (Phaedrus, 277c with my emphasis). Given the saturation of Homer and Hesiod into the psyche of the Athenians, a belief in inspiration would have been common ${ }^{10}$. By using this belief, by simply explaining its consequences, Plato could show how it necessitated an absence of knowledge for the poets and rhapsodes. I do not believe Plato cared whether people believed in inspiration or not, but simply used it to explicate an argument he did believe in. This is the argument that the traditional arts were not on a path to knowledge, so long as they were treated in the way the Athenians were treating them. Once again, then, inspiration is coupled with irony here in the Ion, to help in the successful pedagogy of the Platonic method.

\section{Socrates' Palinode Part I, Phaedrus 244a - 245c}

Although the Ion is undoubtedly the most prolonged Platonic treatment of inspiration, Socrates' second speech in the Phaedrus, where he recants the first, is undeniably the most renowned exposition on the matter. I, like Griswold (1986), will split the speech in two, dealing with here the opening of the palinode where Socrates is seen to describe and apparently extol the traditional forms of inspiration. Yet this opening is, I believe, used solely as a means to bring Phaedrus with Socrates towards the speech's second part, where the dialogue's argument properly begins. In other words, this first part is simply a way of persuading Phaedrus that their approach is a similar one.

Yet again do we notice that this short Socratic description of inspiration is a speech, as opposed to a discussion, and does not stop for retort or argument. Its irony lies in the way it appears to be genuine, but is really a way for Plato to demonstrate the irrationality of this traditional form of inspiration, before

10 As mentioned earlier, though, there is a distinction between the traditional theme of inspiration and what Plato turns it into.

PLATO, The electronic Journal of the International Plato Society, n 8, 2008.

http://gramata.univ-paris1.fr/Plato

(c) All rights of reproduction of any form reserved. 
outlining his own, 'philosophical' inspiration in the speech's second part. I believe the evidence for this lies in the details of each of the three traditional forms of inspiration given initially by Socrates. For one, the mantic prophet supposedly celebrated as the first claimant of inspiration is coupled by Plato in the Republic with begging-priests at Republic, 364b-c, describing them almost like conmen who claim they can use sacrifices and incantations to cleanse any and all injustices conducted by the clients ${ }^{11}$. This ability to 'purify an injustice' is again attributed to the second type of inspiration which also involves possession through prayer. But once more, though, we must consider how far Plato goes in the Republic and Laws to argue against the idea that the gods can in any way be persuaded by prayer and sacrifice. Surely no good can come from such a theory of worship, as it undermines any rational conception of justice. Yet the third class of inspiration is without doubt the most incompatible with what we know of Plato. Are we to believe the following lines to be the true feelings of the same author as that of the Republic, where the 'countless mighty deeds of ancient times' are far more genuinely attacked for the very reason that they were being used in the 'instruction of posterity'?'12

"This (the inspiration of the Muses) seizes a tender, virgin soul and stimulates it to rapt passionate expression, especially in lyric poetry, glorifying the countless mighty deeds of ancient times for the instruction of posterity." Phaedrus, 245 a

Also telling is the fact that when Socrates finishes his outline of these traditional conceptions of inspiration he says, 'such then is the tale'. (Phaedrus, 245b) Yet, when he endeavours to show the fourth type of inspiration, which is really what the dialogue has been leading to, he says 'here then our proof (ámód $\varepsilon i \xi ı \zeta)$ begins' (Phaedrus, 245c $)^{13}$. Another surreptitious jibe is made at the end of this part of the speech, a section of the dialogue often taken literally by commentators. For

\footnotetext{
11 This is recognised and slightly expanded upon by Hackforth (1952), p. 58.

12 Hackforth (1952) and Pieper (1962) argue that Plato is referring here to the acceptable poets argued for in the Republic. I disagree, however, given the total absence of such a qualification and the direct reference to the poets' educational connection.

13 Griswold (1986) prefers the translation 'exposition'. Regardless, though, even an exposition is patently different to a 'tale'.
}

PLATO, The electronic Journal of the International Plato Society, n 8, 2008.

http://gramata.univ-paris1.fr/Plato

(c) All rights of reproduction of any form reserved. 
when Socrates 'declares' that the poetry of the madman will eclipse that of the sane man at Phaedrus, 245a, he makes sure to add how unnecessary skill is in the weighing of this decision.

"But if any man come to the gates of poetry without the madness of the Muses, persuaded that skill alone will make him a good poet, then shall he and his works of sanity with him be brought to nought by the poetry of madness..." Phaedrus, 245a. The emphasis is again my own

It seems the expertise and knowledge of the true professional is not needed for the social acceptance and progression of this profession. Yet, this lack of skill was the very reason we saw Socrates degrade the rhapsode's art in the Ion. As Plato's conception of techne is one of his most consistent throughout his works, this admission as to a lack of expertise in traditionally manic possession must be seen as strong evidence as to his ironic intentions here. As a further point, just as we saw Socrates suggest that he was not responsible for his first speech, so too do we find Socrates attributing this second speech to someone else.

"Now you must understand, fair boy, that whereas the preceding discourse was by Phaedrus, son of Pythocles, of Myrrinous, that which I shall now pronounce is by Stesichorus, son of Euphemus, of Himera." Phaedrus, 243e $-244 \mathrm{a}$

It is clear that Stesichorus is invoked because of the nature of the palinode involved and the myth that he had once had his sight taken away after composing a 'false' tale about Helen of Troy, only to have his sight returned upon his recantation. Yet it also carries with it clear intonations of the literary nature of his discourse $^{14}$. The poetical nature of Phaedrus would surely be interested in such a reference, allowing himself be carried to wherever Socrates leads. Where Socrates

\footnotetext{
${ }^{14}$ The literary aspirations of Plato's arguments in the Phaedrus are once more mentioned by Socrates towards the end of the dialogue. "...tell Lysias that we two went down to the stream, where is the holy place of the Nymphs, and there listened to words which charged us to deliver a message, first to Lysias and all other composers of discourses, secondly to Homer and all others who have written poetry whether to be read or sung..." Phaedrus, 278b-c. Emphasis my own.
}

PLATO, The electronic Journal of the International Plato Society, n 8, 2008. http://gramata.univ-paris1.fr/Plato

(c) All rights of reproduction of any form reserved. 
does lead is to the second part of this speech, where the ironic theme of inspiration becomes transformed into the true purpose of the work.

\section{Socrates' Palinode Part II, Phaedrus 245c - 257b}

Once the traditional forms of inspiration have been presented, and Phaedrus is fully onboard with him, Socrates switches to a fourth 'type' of inspiration. A difference is immediately established by Socrates when he precludes describing this fourth type with an exegesis on the nature of the soul. As noted by Hackforth $^{15}$, although this part of Plato's approach is still a speech, it is 'essentially dialectical'. The establishing conception of soul gives this fourth type of inspiration a sound foundation, an attribute which was lacking in all of the preceding forms. This, then, is where the dialogue proper begins, where a proper understanding of soul is argued for as the best possible source for speech-making and for trying to present to someone one's own position. It is also where a Platonic sense of erotic inspiration is established ${ }^{16}$. The distance between this Platonic sense of divine inspiration and the traditional sense exemplified by the poets is apparent when Socrates warns us that, 'of that place beyond the heavens none of our earthly poets has yet sung, and none shall sing worthily' (Phaedrus, $247 \mathrm{c}$ ). This seems to be telling us directly that the inspiration detailed previously is not at all a reputable source of information. Plato's 'true' Muse, the Muse which is responsible for this fourth type of inspiration is, again, not a simple hypothetical but is named and referred to at Republic $548 \mathrm{~b}^{17}$.

"[S]ince they've neglected the true Muse - that of discussion and philosophy - and have valued physical training more than music and poetry, they haven't been educated by persuasion but by force."

\footnotetext{
${ }^{15}$ Hackforth (1953) p. 64.

${ }^{16}$ One of the ways Plato distances his erotic conception of inspiration is in how he describes the realm his inspiration comes from as 'supra-heavenly', a realm which can only be seen as being identical with the Forms and comparatively 'truer' than the traditional, Olympian realm.

17 A detailed examination of Plato's 'true' Muse can be found in Penelope Murray's, "Plato's Muses: The Goddesses That Endure" in, Cultivating the Muse: Struggles for Power and Inspiration in Classical Literature, 2002.
}

PLATO, The electronic Journal of the International Plato Society, n 8, 2008. http://gramata.univ-paris1.fr/Plato

(c) All rights of reproduction of any form reserved. 
With this the words 'inspiration' and 'Muse' lose all traditional meaning and become subsumed by a new, Platonic senses. In this way, Plato's use of inspiration can be seen in its proper light. This is simply as a method of introducing interlocutors and the audience they represent into a discussion which ultimately draws them towards the detailed intricacies of Plato's own philosophy. Focussing on the first part of Socrates' palinode (from Phaedrus 244a - 245c), and not realising its role as facilitator in what follows in the dialogue, is then to give up on the dialogue and ignore the call that the concept of dialogue makes on each of us.

\section{Conclusion}

In conclusion, this paper has examined the theme of divine inspiration in the Phaedrus and Ion and argued that Plato's ironic intonation is consistent in both. By analysing how the characters of Phaedrus and Ion are presented by Plato in each work, I have attempted to show how operative the inspiration theme is, not only in luring these characters into the dialogue in the first place, but also in bringing them towards a new, shared understanding.

\section{Bibliography}

Bowen, A.J., Xenophon's Symposium, Aris and Phillips, 1998

CoOPER, John, M, ed., intro., and notes, Plato - Complete Works, Hackett, 1997

Ferrari, G.R.F., Listening to the Cicadas - A Study of Plato's Phaedrus, Cambridge University Press, 1987

Griswold, Charles L. Jr., Self-Knowledge in Plato's Phaedrus, Yale University Press, 1986

HaCKforth, R., Plato’s Phaedrus, Cambridge, 1952

Moravcsik, Julius, \& Temko, Philip eds., Plato on Beauty, Wisdon, and the Arts, Rowman \& Allanheld, 1982

Pieper, Josef, Enthusiasm and Divine Madness - On the Platonic Dialogue Phaedrus, translated by Richard and Clara Winston, St. Augustine's Press, 1962

SPENTZOU, Efrossini \& Fowler, Don, eds., Cultivating the Muse: Struggles for Power and Inspiration in Classical Literature, Oxford University press, 2002.

PLATO, The electronic Journal of the International Plato Society, n 8, 2008. http://gramata.univ-paris1.fr/Plato

(c) All rights of reproduction of any form reserved. 
TigerstedT, E.N., "Furor Poeticus: Poetic Inspiration in Greek Literature Before Democritus and Plato", Journal of the History of Ideas, XXXI [1970], 16378

Plato's Idea of Poetical Inspiration, Commentationes Humanarum Litterarum, Helsinki, 1969

Woodruff, Paul, Two Comic Dialogue: Ion and Hippias Major, Hackett, 1983

PLATO, The electronic Journal of the International Plato Society, n 8, 2008. http://gramata.univ-paris1.fr/Plato

(c) All rights of reproduction of any form reserved. 